\section{Improvement of In Vitro Proliferation and Elongation of Habanero Pepper Shoots (Capsicum chinense Jacq.) by Temporary Immersion}

\author{
Jericó J. Bello-Bello, Adriana Canto-Flick, Eduardo Balam-Uc, \\ Eunice Gómez-Uc, and Manuel L. Robert \\ Unidad de Bioquímica y Biología Molecular de Plantas, Centro de \\ Investigación Científica de Yucatán, Calle 43 \# 130 colonia Chuburná de \\ Hidalgo, Mérida, Yucatán, 97200, México
}

\author{
Lourdes G. Iglesias-Andreu \\ Instituto de Biotecnología y Ecología Aplicada, Universidad Veracruzana, \\ Campus para la Cultura, las Artes y el Deporte. Av. de las Culturas \\ Veracruzanas No. 101, Colonia Emiliano Zapata, C.P. 91090, Jalapa, \\ Veracruz, México
}

Nancy Santana-Buzzy
Unidad de Bioquímica y Biología Molecular de Plantas, Centro de Investigación
Científica de Yucatán, Calle 43 \# 130 colonia Chuburná de Hidalgo, Mérida,
Yucatán, 97200, México

Additional index words. micropropagation, multiple shoots, Modular Temporary Immersion Bioreactor (BioMINTTM

\begin{abstract}
This article describes the performance of nodal segments from Habanero pepper (Capsicum. chinense) during shoot induction and elongation under different semisolid and liquid culture conditions with various degrees of ventilation in which they were exposed to different levels of immersion and growth regulators. The ethylene content in non-ventilated containers, the age of the explant donor plants as well as the effect of thidiazuron and paclobutrazol on shoot induction and of gibberellic acid and $\mathrm{AgNO}_{3}$ on shoot elongation were also evaluated. A temporary immersion bioreactor (BioMINT $^{\mathrm{TM}}$ ) was used for the multiplication and elongation of isolated shoots with very good results. We report an efficient protocol for the in vitro propagation of Habanero pepper that produces plants with a high survival rate when transplanted to soil.
\end{abstract}

Habanero pepper (Capsicum chinense) is an important horticultural crop in the southeast of Mexico. Although other Solanaceae members easily undergo morphogenesis in vitro, the species of the genus Capsicum sp. are highly recalcitrant. Recalcitrance, the inability of plant cells, tissues, and organs to respond to tissue culture (Benson, 2000), can occur at any stage of a culture process and as yet, very little is known regarding its causal factors. The success of a plant biotechnology project can largely depend on the ability to regenerate whole plants from in vitro cultures. A few common observations in Capsicum regeneration include formation of profuse leafy structure instead of shoot buds, shoot buds that do not elongate (see, e.g., Hyde and Phillips, 1996), or induction of somatic embryos that fail to germinate (Steinitz et al., 2003). Several attempts have been made to achieve plant regeneration from different explants: shoot tips (Christopher

Received for publication 2 Oct. 2009. Accepted for publication 4 Jan. 2010

${ }^{1}$ To whom reprint requests should be addressed; e-mail buzzy@cicy.mx. and Rajam, 1994), rooted hypocotyls (ValeraMontero and Ochoa-Alejo, 1992), leaf, stem, hypocotyls, cotyledons, roots, shoot tips and zygotic embryos (Agrawal et al., 1989), and induced somatic embryogenesis (Binzel et al., 1996; Buyucalaka and Mavituna, 1996; Kintzios et al., 2000; López-Puc et al., 2006; Zapata-Castillo et al., 2007). Most of them have shown that plant regeneration in chili pepper is severely limited (Franck-Duchenne et al., 1998; SantanaBuzzy et al., 2006; Steinitz et al., 1999).

Tissue culture responses are influenced by three main factors: "whole plant" physiology of the donor, in vitro manipulations, and in vitro plant stress physiology (Benson, 2000). The culture environment per se may provoke stress responses that promote recalcitrance (Benson, 2000). The production ceived considerable attention as a possible factor in culture recalcitrance. Tissue culture can promote inhibitory interactive effects between exogenous and endogenous hormones, and recalcitrance can be associated with the overproduction and accumulation of ethylene in the culture vessel. Ethylene is involved in of ethylene by plant tissue cultures has re- many morphogenetic responses (for a review, see Kumar et al., 1998) because it can both promote and inhibit in vitro morphogenesis.

Recently, Santana-Buzzy et al. (2005, 2006) reported the ethylene effects on explants of Habanero pepper during shoot induction; both studies gave evidence of the high sensibility of this species to the accumulation of ethylene in culture containers. In this species (C. chinense) also were reported two efficient somatic embryogenesis protocols from hypocotyls, direct and indirectly (López-Puc et al., 2006) and indirectly (Zapata-Castillo et al., 2007). Sanatombi and Sharma (2008) reported the proliferation of multiple shoot buds from shoot-tip explants. However, the low frequency of elongated shoots and somatic embryos converted to whole plants continues to occupy the attention of groups involved in investigations on the species of this genus. The aim of this study was to evaluate the effect of the age of the explant, the composition of the culture medium, and a temporary immersion culture system on shoot proliferation and elongation.

\section{Material and Methods}

Explant source. Seeds of the cultivar RPS (red type) of Habanero pepper (Capsicum chinense Jacq.) were first submerged in ethanol at $70 \%$ (v/v) for $5 \mathrm{~min}$ and subsequently in a solution of commercial sodium hypochlorite (Cloralex $^{\mathrm{TM}}, 6 \%$ a. i.; Distribuidora Alen S.A. de C V., Santa Catarina Nuevo León, México) diluted to $30 \%(\mathrm{v} / \mathrm{v})$ for $15 \mathrm{~min}$ with constant stirring. The seeds were then rinsed three times with sterile distilled water. For germination, the seeds were placed in baby food jars containing $20 \mathrm{~mL}$ of Murashige and Skoog (MS) (Murashige and Skoog, 1962) medium supplemented with $1.15 \mu \mathrm{M}$ gibberellic acid $\left(\mathrm{GA}_{3}\right)$. The medium was solidified with $0.22 \%$ (w/v) Gelrite ${ }^{\mathrm{TM}}$ (Applied Bioscience Consultants and Distributor, Mumbai, India) and adjusted to $\mathrm{pH} 5.7$ before sterilization in an autoclave. The jars were covered with propylene lids and incubated in darkness at $25 \pm 2{ }^{\circ} \mathrm{C}$. On germination, plantlets were transferred to the same MS medium without growth regulators. Photoperiod was $16 \mathrm{~h}$ light (40 to $50 \mu \mathrm{mol} \cdot \mathrm{m}^{-2} \cdot \mathrm{s}^{-1}$ ) at $25 \pm 2{ }^{\circ} \mathrm{C}$. These plants were used as a source of explants for all the experiments and, unless specified, they were cultured on semisolid media at $25 \pm 2{ }^{\circ} \mathrm{C}$ with a photoperiod of $16 \mathrm{~h}$ light (40 to 50 $\left.\mu \mathrm{mol} \cdot \mathrm{m}^{-2} \cdot \mathrm{s}^{-1}\right)$.

Effect of culture conditions on shoot formation. Nodal segments from 60 to $65-\mathrm{d}$ old in vitro-grown plants were cultured in liquid MS medium supplemented with 3.4 $\mu \mathrm{M}$ of thidiazuron (TDZ) $(40 \mathrm{~mL}$ of medium per flask). The treatments evaluated were: 1 ) totally submerged explants in liquid medium shaking flasks at $100 \mathrm{rpm}$ with rubber stoppers; 2) partially submerged explants in liquid medium at rest using a $0.5-\mathrm{cm}$ thick piece of polyurethane (sponge) as a support placed at the bottom of each flask; and 3) on a support explants in contact with the liquid medium through a $0.8-\mathrm{cm}$ thick polyurethane 
sponge. As a control, explants were cultured on semisolid medium.

The effect of ventilation and the ethylene concentration in the culture vessels was also evaluated using ventilated and nonventilated containers. The ethylene was measured by gas chromatography. Two-milliliter samples of the culture container atmosphere were withdrawn with a syringe. The ethylene was measured by gas chromatography, using a chromatograph (8690 Series II; HPTM). The column used was a GS-Q FSOT $\left(\right.$ Alltech ${ }^{\text {TM }}, 30 \mathrm{~mL} \times 0.53 \mathrm{~mm}$ ID), and nitrogen was the carrier gas at a flow rate of $10 \mathrm{~mL} \cdot \mathrm{min}^{-1}$. The oven temperature was $70{ }^{\circ} \mathrm{C}$. The injector and detector temperatures were $200^{\circ} \mathrm{C}$. Pure ethylene was used as external standard, with retention time of 2.2 min, with a FID detector.

Effect of explant age on shoot formation. Nodal segments from plants of different ages (see Table 1) were cultured in MS medium supplemented with $3.4 \mu \mathrm{M}$ of TDZ.

Effect of paclobutrazol and thidiazuron on shoot formation. Nodal segments (65-dold) from aseptic plants were cultured in semisolid MS medium in ventilated containers. Different concentrations of paclobutrazol (PAC) and TDZ were evaluated (see Table 2). The cultures were incubated for a period of 8 weeks as previously described.

Effect of various growth regulators on shoot elongation. To evaluate shoot elongation, explants containing neoformations and small shoots ( 0.3 to $0.5 \mathrm{~cm}$ high) were cultured in different concentrations of $\mathrm{GA}_{3}$ and $\mathrm{AgNO}_{3}$ on semisolid medium. Twentyfive explants per treatment were cultured.

Shoot induction in temporary immersion culture. Nodal segments from 65-d-old plantlets were cultured under temporary immersion conditions using a Modular Temporary Immersion Bioreactor [BioMINT ${ }^{\mathrm{TM}}$; Patent No. PA/a/2004/003837, Centro de Investigación Científica de Yucatán (CICY), Yucatán, México] designed by Robert et al. (2006). The immersion frequencies evaluated were 2,4 , and $6 \mathrm{~min}$ every $4,6,8$, and $12 \mathrm{~h}$. The composition of the liquid medium used was MS supplemented with $3.4 \mu \mathrm{M}$ of TDZ and $3.4 \mu \mathrm{M}$ of PAC. Thirty-six bioreactors were used distributed in 12 treatments with three repetitions. Each bioreactor contained 10 explants in $100 \mathrm{~mL}$ of liquid medium.

Shoot elongation and rooting in temporary immersion culture. Isolated shoots with an average height of $1 \mathrm{~cm}$ were transferred to $100 \mathrm{~mL}$ MS liquid medium supplemented with $\mathrm{GA}_{3}$ $(2.77 \mu \mathrm{M})$ and $\mathrm{AgNO}_{3}(10 \mu \mathrm{M})$ using three bioreactors with 10 explants each. The shoots were immersed for 2 min every 8 and $12 \mathrm{~h}$.

Data analysis. Data were analyzed by an analysis of variance and Student's $t$ test with SPSS 11.5 for Windows program (SPSS Inc., Chicago, IL) and comparison of means according to the Tukey test $(P \leq 0.05)$.

\section{Results}

Effect of culture conditions. Shoots formed under all conditions tested; however, their development and survival were affected by the atmosphere in the culture dish. The best morphogenic response was observed in explants cultured in semisolid ventilated medium (Fig. 1), which also presented the lowest mortality rate $(11 \%)$. The first shoots (three to four shoots per explants) emerged after 2 weeks in culture (Fig. 2D). The explants cultured in semisolid non-ventilated medium formed callus in the epidermis and at the base of the shoots. The shoots died in a very short period of time in all nonventilated conditions, probably as a result of the accumulation of ethylene in the culture vessel. Under ventilated conditions, the mortality rate was higher (Fig. 1) when the explants were submerged in liquid medium (Fig. 2). This could be attributed to a reduction of available oxygen for the explants. The results suggest that, during shoot induction and proliferation, the concentration of ethylene in the culture vessels had a greater effect on the explants than the reduction of available oxygen.

Figure 3 shows that no ethylene accumulation was detected in nonventilated

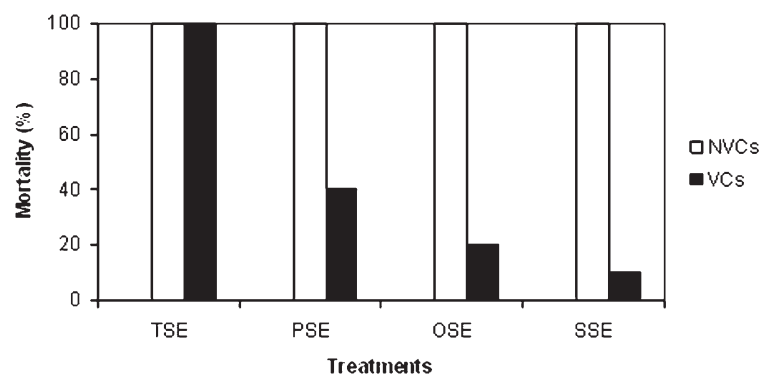

Fig. 1. Mortality of explants in different treatments. (A) Totally submerged explants (TSE); (B) partially submerged explants (PSE); (C) partially submerged explants on a support (OSE); (D) on semisolid medium (SSE). White bars $=$ non-ventilated containers $(\mathrm{NVCs})$; dark bars = ventilated containers (VCs).

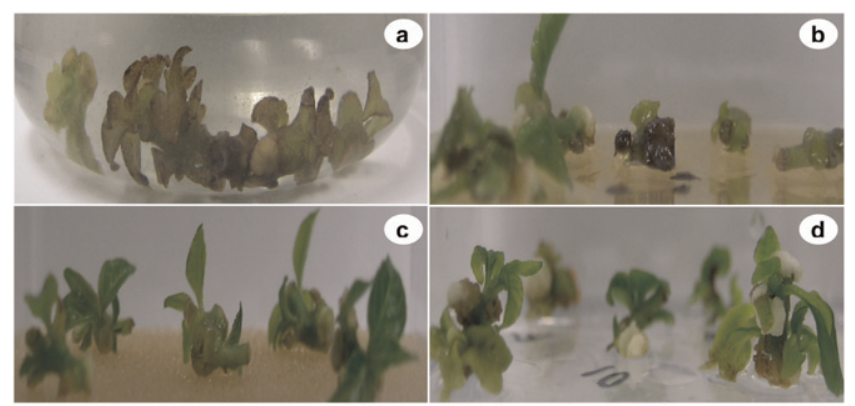

Fig. 2. Explant appearance at $25 \mathrm{~d}$ of culture in ventilated containers: (A) totally submerged explants; (B) partially submerged explants; (C) on a support explants; and (D) on semisolid medium explants.

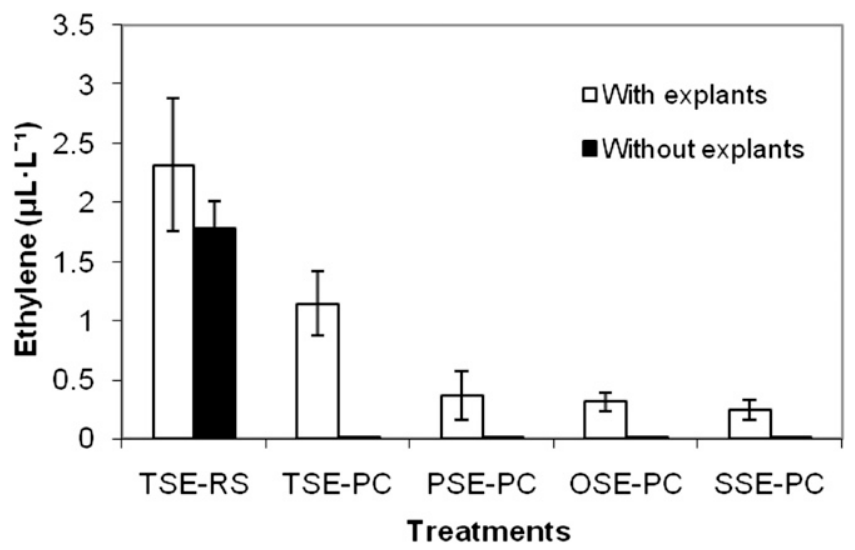

Fig. 3. Ethylene production in non-ventilated containers during in vitro culture of Habanero pepper. (A) totally submerged explants with a rubber stopper (TSE-RS); (B) totally submerged explants with polypropylene closure (TSE-PC); (C) partially submerged explants with polypropylene closure (PSEPC); (D) explants on support with polypropylene closure (OSE-PC); and (E) semisolid medium explants with polypropylene closure (SSE-PC). Vertical bars represent $\pm \operatorname{SE}(n=3)$. 
conditions without explants or in ventilated conditions with explants; however, this gas regulator was detected in all non-ventilated treatments. The ethylene content in nonventilated conditions (with and without explants) was higher when rubber stoppers and polypropylene caps were used (Fig. 3A-B). In the treatments without explants, no ethylene was detected except in the nonventilated conditions with rubber stoppers (with and without explants), in which the highest accumulations of ethylene were registered. The highest ethylene concentrations were registered when the explants were totally submerged in nonventilated conditions with rubber stoppers (Fig. 3A) both in containers without explants $\left(1.8 \mu \mathrm{L} \cdot \mathrm{L}^{-1}\right)$ and in containers with explants $\left(2.3 \mu \mathrm{L} \cdot \mathrm{L}^{-1}\right)$, suggesting that the rubber stoppers release ethylene in the containers. In contrast, in treatments in which polypropylene caps were used, no ethylene was detected in containers without explants and without ventilation. The lowest ethylene concentration was detected when the explant was cultured on semisolid medium with a polypropylene cap (Fig. 3E).

Effect of explant age. Table 1 shows the response of explants taken from plants of different physiological ages. As the age of the plant increased, the number of explants producing shoots decreased. Although the number of shoots formed did not differ significantly among the different ages, the 40-dold explants responded faster with $75 \%$ of the explants forming shoots $(5.33 \pm 0.44$ shoots per explant) after 2 weeks (Fig. 4 ) in contrast with the older ones that started 1 week later.

Effect of paclobutrazol and thidiazuron on regeneration. Table 2 shows the effect of various concentrations of PAC and TDZ on shoot induction and proliferation. The best response was obtained with $3.4 \mu \mathrm{M}$ of PAC + $3.4 \mu \mathrm{M}$ of TDZ, in which $75 \%$ of the explants formed an average of 14.5 shoots per explant, a significant difference in comparison with all other treatments. However, the shoots formed from neoformations (Fig. 5A) were only able to produce their primordial leaves (Fig. 5B) after which their development stopped. This behavior could be attributed to the presence of PAC, which inhibited shoot elongation. The number of formed shoots was significantly lower in treatments with only PAC or TDZ (Table 2).

Effect of gibberellic acid and $\mathrm{AgNO}_{3}$ on shoot elongation in semisolid medium. As shown in Table 3, an increase in the height of

Table 1. Response of Habanero pepper (Capsicum chinense Jacq.) explants at different ages during multiple shoot induction after 8 weeks of culture.

\begin{tabular}{lcc}
\hline $\begin{array}{l}\text { Age of } \\
\text { explant } \\
\text { (days) }\end{array}$ & $\begin{array}{c}\text { Explants with } \\
\text { shoots }(\%)\end{array}$ & $\begin{array}{c}\text { Shoots/explant } \\
\text { greater than } \\
0.5 \mathrm{~cm}(\text { mean } \pm \mathrm{SE})\end{array}$ \\
\hline 40 & 75 & $5.33 \pm 0.44 \mathrm{a}^{\mathrm{z}}$ \\
65 & 65 & $5.38 \pm 0.34 \mathrm{a}$ \\
95 & 55 & $4.36 \pm 0.30 \mathrm{ab}$ \\
130 & 20 & $3.25 \pm 0.25 \mathrm{~b}$ \\
\hline
\end{tabular}

${ }^{\mathrm{z}}$ Means with different letters are significantly different (Tukey, $P \leq 0.05$ ). the newly formed shoots was registered in all treatments containing $\mathrm{GA}_{3}$, whereas $\mathrm{AgNO}_{3}$ on its own had no effect whatsoever. However, the combination of $\mathrm{GA}_{3}$ with $\mathrm{AgNO}_{3}$ $(10 \mu \mathrm{M})$ proved to be the most effective treatment with greater elongation and development of the shoots forming prominent stems and bright green leaves (Fig. 5C) after $25 \mathrm{~d}$ of culture. With $\mathrm{GA}_{3}(2.77 \mu \mathrm{M})$ alone, the shoots were able to elongate but showed chlorosis with an etiolated appearance as a result of very thin elongated stems, long internodes, and poorly developed, pale green leaves.

These results suggest that $\mathrm{GA}_{3}$ is essential for shoot elongation, whereas $\mathrm{AgNO}_{3}$ has a predominant effect on the quality of the shoots, probably as a result of its inhibiting effect on ethylene receptors present in the plants of this species.

Temporary immersion culture. Culturing explants with neoformations at an early developmental stage under temporary immersion induced proliferation and elongation of the neoformations present in the explants. Table 4 shows that an average of 25 to 30 shoots per explant developed after only $21 \mathrm{~d}$ of culture compared with 14.5 in semisolid medium. The shoots also elongated faster under temporary immersion reaching $4 \mathrm{~cm}$ versus $6 \mathrm{~cm}$ of height in semisolid medium. The best results were obtained when the immersion of the shoots was 2 min every 8 h (Fig. 5D).

\section{Discussion}

Despite the relative success reported on shoot organogenesis from foliar explants
(Husain et al., 1999; Venkataiah et al., 2003) or hypocotyls (Arous et al., 2001; Ochoa-Alejo and Ireta-Moreno, 1990) and somatic embryogenesis from immature zygotic embryos (Binzel et al., 1996) or anthers and isolated microspores (Barany et al., 2005; Koleva-Gudeva et al., 2007), Capsicum is considered to be a recalcitrant genus to in vitro morphogenesis. As a result of their greater responsiveness to in vitro plant regeneration, cotyledons remain the explant of choice (Golegaonkar and Kantharajah, 2006; Mathew, 2002; PozuetaRomero, et al., 2001; Venkataiah et al., 2001). Regeneration, however, is frequently reported to consist of bud-like structures and rarely of well-developed shoots (Arroyo and Revilla, 1991; Ochoa-Alejo and Ireta-Moreno, 1990; Ramirez-Malagón and Ochoa-Alejo, 1996; Steinitz et al., 1999). A strong influence of culture conditions and genotypes has also been demonstrated (Venkataiah et al., 2003). By using cotyledon explants (Agrawal et al., 1989; Mathew, 2002; Venkataiah et al., 2006) and by applying the most common regeneration protocols for hot pepper (Mathew, 2002; Venkataiah et al., 2001), Mezghani et al. (2007) produced shoot buds for a hot pepper genotype (cv. Baklouti). However, genetic engineering in pepper is still restricted by the low morphogenetic potential of this species (Mathew, 2002; Steinitz et al., 1999). Santana-Buzzy et al. $(2005,2006)$ reported high sensibility to ethylene during in vitro culture of Habanero pepper. According to Kumar et al. (1998), one of the main effects of ethylene on in vitro cultures is the inhibition of cellular division, which consequently affects

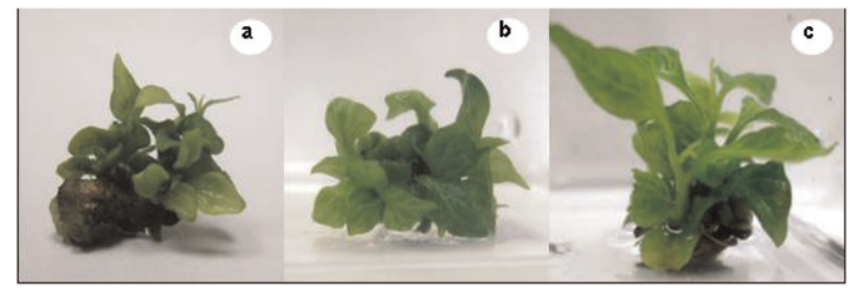

Fig. 4. Habanero pepper shoot proliferation from nodes cultured in solid Murashige and Skoog medium supplemented with thidiazuron $(3.4 \mu \mathrm{M})$ after (A) 3 weeks in culture; (B) 5 weeks; and (C) 8 weeks.

Table 2. Effect of thidiazuron (TDZ) and paclobutrazol (PAC) on multiple shoot induction in Habanero pepper (Capsicum chinense Jacq.) after 8 weeks of culture.

\begin{tabular}{clcc}
\hline \multicolumn{2}{c}{$\begin{array}{c}\text { Growth } \\
\text { regulators }(\mu \mathrm{M})\end{array}$} & $\begin{array}{c}\text { Explants forming } \\
\text { shoots }(\%)\end{array}$ & $\begin{array}{c}\text { Shoots/explant greater than } 0.5 \mathrm{~cm} \\
(\text { mean } \pm \mathrm{sE})\end{array}$ \\
\cline { 1 - 2 } TDZ & PAC & 73.3 & $1.18 \pm 0.12 \mathrm{~d}^{2}$ \\
0 & 0 & 66.6 & $1.20 \pm 0.13 \mathrm{~d}$ \\
0 & 1.17 & 80.0 & $1.16 \pm 0.11 \mathrm{~d}$ \\
0 & 3.4 & 73.3 & $1.27 \pm 0.14 \mathrm{~d}$ \\
3.4 & 6.8 & 60.0 & $3.88 \pm 0.30 \mathrm{c}$ \\
3.4 & 0 & 66.6 & $7.20 \pm 0.35 \mathrm{~b}$ \\
3.4 & 1.17 & 75.0 & $14.55 \pm 1.02 \mathrm{a}$ \\
3.4 & 3.4 & 53.3 & $9.00 \pm 0.65 \mathrm{~b}$ \\
1.1 & 6.8 & 45.0 & $2.3 \pm 0.33 \mathrm{~cd}$ \\
2.3 & 3.4 & 45.0 & $3.0 \pm 0.37 \mathrm{c}$ \\
4.5 & 3.4 & 55.0 & $8.20 \pm 0.22 \mathrm{~b}$ \\
\hline
\end{tabular}

${ }^{\mathrm{z}}$ Means with different letters are significantly different (Tukey, $P \leq 0.05$ ). 

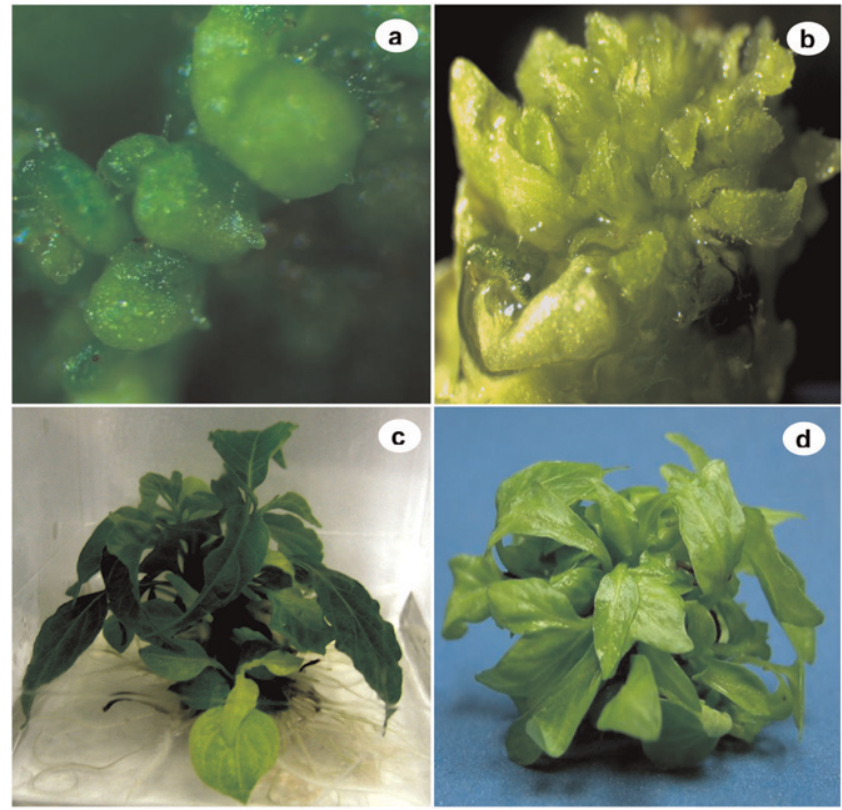

Fig. 5. Induction and proliferation of neoformations or de novo shoots in Habanero pepper in culture medium supplemented with thidiazuron $(3.4 \mu \mathrm{M})$ and PAC $(3.4 \mu \mathrm{M})$ : (A) formation of monopolar structures directly from the explant; (B) proliferation of de novo buds; (C) development of the new buds in medium supplemented with gibberellic acid $(2.77 \mu \mathrm{M})+\mathrm{AgNO}_{3}(10 \mu \mathrm{M})$; and (D) development in the temporary immersion system in medium M4.

Table 3. Effect of gibberellic acid $\left(\mathrm{GA}_{3}\right)$ and $\mathrm{AgNO} 3$ on shoot elongation in Habanero pepper (Capsicum chinense Jacq.) after $25 \mathrm{~d}$ of culture.

\begin{tabular}{lccc}
\hline \multicolumn{2}{c}{ Growth regulators $(\mu \mathrm{M})$} & $\begin{array}{c}\text { Response } \\
(\%)\end{array}$ & $\begin{array}{c}\text { Shoot length }(\mathrm{cm}) \\
(\text { mean } \pm \mathrm{SE})\end{array}$ \\
\hline $\mathrm{GA}_{3}$ & $\mathrm{AgNO}$ & 60 & $1.15 \pm 0.24 \mathrm{~b}^{\mathbf{2}}$ \\
0 & 0 & 70 & $1.25 \pm 0.21 \mathrm{~b}$ \\
0 & 10 & 70 & $1.30 \pm 0.22 \mathrm{~b}$ \\
2.77 & 30 & 80 & $3.94 \pm 0.33 \mathrm{a}$ \\
2.77 & 0 & 80 & $4.09 \pm 0.26 \mathrm{a}$ \\
2.77 & 10 & 80 & $4.10 \pm 0.30 \mathrm{a}$ \\
\hline
\end{tabular}

${ }^{\mathrm{z}}$ Means with different letters are significantly different (Tukey, $P \leq 0.05$ ).

Table 4. Comparison culture methods on Habanero pepper shoot proliferation and elongation rate in semisolid medium and in temporary immersion in BioMINT ${ }^{\mathrm{TM}}$ bioreactors.

\begin{tabular}{lcr}
\hline & Semisolid medium & \multicolumn{1}{c}{ BioMINT $^{\text {TM }}$} \\
\hline Shoots proliferation $($ mean $\pm \mathrm{SE})$ & $14.55 \pm 1.02 \mathrm{~b}^{\mathrm{z}}$ & $25.27 \pm 1.20 \mathrm{a}$ \\
Shoots elongation $(\mathrm{cm})($ mean $\pm \mathrm{SE})$ & $4.14 \pm 0.17 \mathrm{~b}$ & $5.76 \pm 0.18 \mathrm{a}$ \\
\hline
\end{tabular}

${ }^{\mathrm{z}}$ Means with different letters are significantly different (Student's $t$ test, $P \leq 0.05$ ).

the development of morphogenesis at very low concentrations. In sugarcane, Taylor et al. (1994) reported that ethylene caused a reduction in cellular division, whereas Reid (1995) detected that the highest ethylene content in vitro occurred during manipulation and subculture of the explants, apparently as a product of phenolic oxidation of the explants themselves.

Growth regulators have been widely used to improve plant regeneration capacity in species recalcitrant to in vitro morphogenesis. PAC has proved to be one of the most effective growth regulators for inducing organogenesis and somatic embryogenesis (Chen et al., 2005; Nagaraju et al., 2002; Opatrná et al., 1997; Thakur et al., 2006; Ziv and Ariel, 1991; Ziv et al., 1994), particularly in recalcitrant species. Besides the capacity to increase the multiplication rate and inhibit $\mathrm{GA}_{3}$ synthesis, PAC has also been attributed to the ability to confer stress tolerance to regenerated plants, which could allow us to infer that these plantlets might show a higher survival rate during their acclimatization. TDZ (N-phenyl-N-1,2,3-thiadiazol-5-ylurea) is a phenylurea compound that has been investigated for cytokinin activity (Huetteman and Preece, 1993). Of the tested cytokinins, TDZ at 0.23 to $9.18 \mathrm{mM} \cdot \mathrm{L}^{-1}$ promoted the highest frequency of shoots from shoot meristem explants in some species. The lowest concentration of TDZ $\left(0.23 \mathrm{~mm} \cdot \mathrm{L}^{-1}\right)$ also induced 4.2 shoots/explant. The maximum number of shoot proliferation demonstrates the high cytokinin activity of TDZ as reported for several other species (Huetteman and Preece, 1993). Compared with most other compounds with cytokinin activity, lower concentrations of TDZ can stimulate axillary shoot proliferation in many plants, whereas higher TDZ concentrations may result in the formation of both axillary and adventitious shoots (Huetteman and Preece, 1993; Yusnita et al., 1990). High rates of shoot proliferation, often desirable for efficient micropropagation, may include both axillary and adventitious shoots. Agrawal et al. (1988) reported the use of shoot tip explants of Capsicum for micropropagation and it was observed that the shoots were formed de novo and were not the result of the induction of axillary buds. If clonal fidelity is desired, however, TDZ or other cytokinins must be used at levels that stimulate only axillary shoot growth, thereby avoiding potential somaclonal variants from adventitious shoots.

On the other hand, culture of isolated shoots under temporary immersion using a Modular Temporary Immersion Bioreactor (BioMINT ${ }^{\mathrm{TM}}$ ) promoted and increased the multiplication rate and shoot elongation, which are the main limitations for the practical application of in vitro regeneration of Habanero pepper. Under these culture conditions, a high frequency of neoformations was observed, which subsequently formed shoots. The formation and abundance of these morphogenetic structures most likely originated from pre-existent buds, which are probably stimulated to form de novo structures by the substitution of PAC for $\mathrm{GA}_{3}$. In a study of Hevea brasilensis, Martre et al. (2001) found that explants exposed to continuous immersion presented abnormal levels of respiration brought about by oxidative stress, resulting in death by asphyxiation. Lorenzo et al. (1998), working with sugar cane, observed a similar behavior in explants treated with $\mathrm{GA}_{3}$ after being treated with PAC. Elongated shoots rooted in liquid medium showed greater vigor and development with increased multiplication. Shoots cultured under temporary immersion conditions showed normal elongation allowing the development and acclimatization of whole plants once removed from the bioreactors.

Despite the recalcitrance of these species to regeneration, in particular to in vitro shoot elongation, the results presented in this study indicate that plant regeneration of Habanero pepper can be optimized through the adequate management of growth regulators, the age of the explants, and the culture system used, among other factors, The protocol proposed increases the efficiency of the process $(25.27 \pm 1.20$ shoots per explant) using a semisolid medium (MS) containing PAC and TDZ (3.4 $\mu \mathrm{M}$, respectively) during the induction stage. Shoot proliferation and elongation take place in liquid medium containing $\mathrm{GA}_{3}(2.77 \mu \mathrm{M})$ and $\mathrm{AgNO}_{3}(10 \mu \mathrm{M})$ under temporary immersion conditions. The synergism between PAC and cytokinins has 


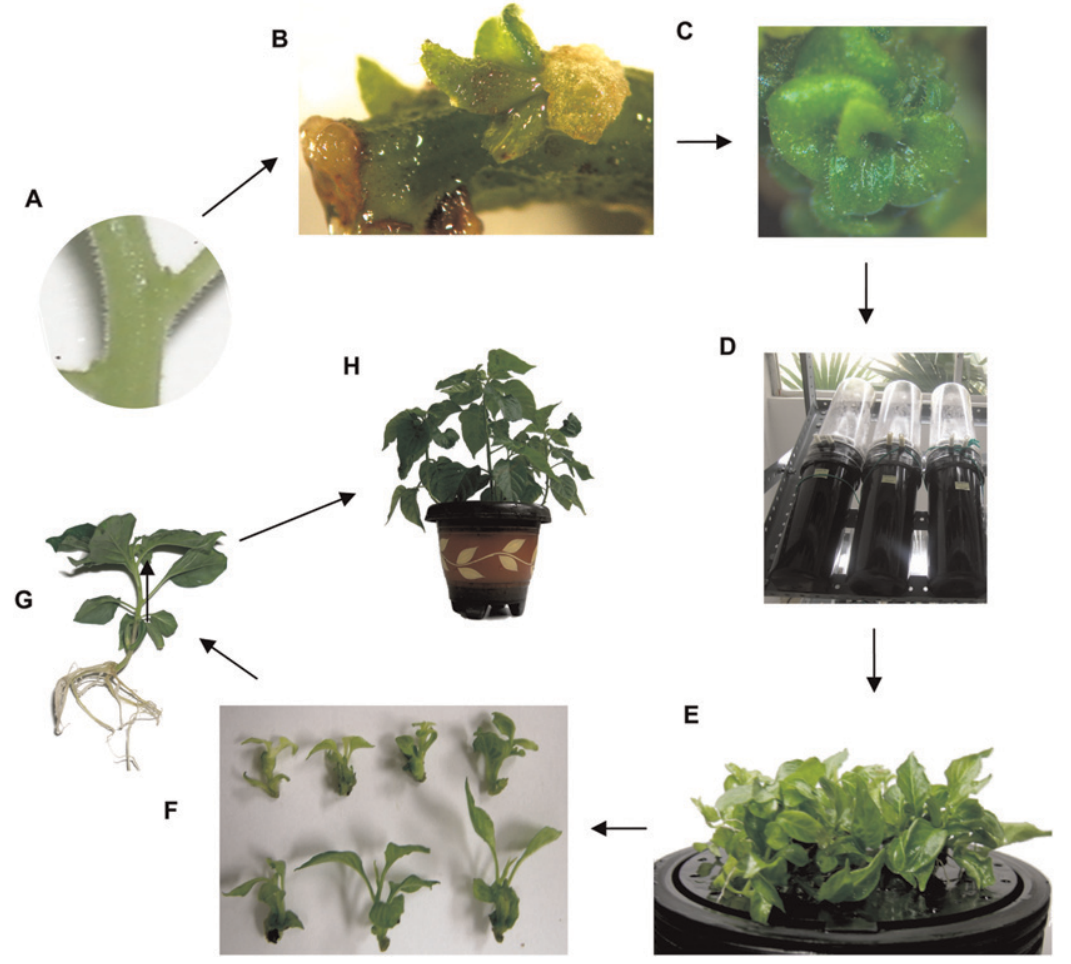

Fig. 6. Scheme for in vitro regeneration and development in Habanero pepper plants: (A) initial explant; (B) direct organogenesis (solid medium); (C) monopolar structures vascularly connected with explant; (D) shoot development; (E) shoot proliferation and development (temporary immersion); (F) shoot elongation under temporary immersion conditions; $(\mathbf{G})$ rooted shoots; $(\mathbf{H})$ plant transferred to substrate and acclimatized.

been observed in in vitro culture of potato (Opatrná et al., 1997), sugarcane (Lorenzo et al., 1998), pineapple (Escalona et al., 1999), and lilium (Chen et al., 2005; Thakur et al., 2006).

In conclusion, an efficient protocol for high frequency of shoot multiplication and plant regeneration of Capsicum through direct organogenesis was developed (Fig. 6). The shoot elongation was overcome by the use of Modular Temporary Immersion Bioreactors (BioMINT). Elongated shoots rooted and grew into normal plants.

\section{Literature Cited}

Agrawal, S., N. Chandra, and S.L. Kothari. 1988. Shoot-tip culture of pepper for micropropagation. Curr. Sci. 57:1347-1349.

Agrawal, S., N. Chandra, and S.L. Kothari. 1989. Plant regeneration in tissue cultures of pepper (Capsicum annuиm L. cv. mathania). Plant Cell Tiss. Org. Cult. 16:47-55.

Arous, S., M. Boussaïd, and M. Marrakchi. 2001. Plant regeneration from zygotic embryo hypocotyls of Tunisian chili (Capsicum annuum L.). J. Appl. Hort. 3:17-22.

Arroyo, R. and M.A. Revilla. 1991. In vitro plant regeneration from cotyledon and hypocotyl segments in two bell pepper cultivar. Plant Cell Rep. 10:414-416.

Barany, I., P. González-Melendi, B. Fadón, J. Mitykót, M. Risueño, and P. Testillano. 2005. Microspore-derived embryogenesis in pepper (Capsicum annuum L.): Subcellular rearrangements through development. Biol. Cell 97:709-722.
Benson, E. 2000. Special Symposium: In vitro plant recalcitrance: An introduction. In Vitro Cell. Dev. Biol. Plant 36:141-148.

Binzel, M.L., N. Sankhla, S. Joshi, and D. Sankhla. 1996. Induction of direct somatic embryogenesis and plant regeneration in pepper (Capsicum annuum L.). Plant Cell Rep. 15:536-540.

Buyucalaka, S. and F. Mavituna. 1996. Somatic embryogenesis and plant regeneration of pepper in liquid media. Plant Cell Tiss. Org. Cult 46:227-235. of the growth retardant paclobutrazol on large-scale micropropagation of daylily (Hemerocallis spp.). In Vitro Cell. Dev. Biol. Plant 41:58-62.

Christopher, T. and M.V. Rajam. 1994. In vitro clonal propagation of Capsicum spp. Plant Cell Tiss. Org. Cult. 38:25-29.

Escalona, M., J.C. Lorenzo, B. González, M Daquinta, J.L. González, Y. Desjardins, and C.G. Borroto. 1999. Pineapple (Ananas comosus L. Merr) micropropagation in temporary immersion systems. Plant Cell Rep. 18:743-748.

Franck-Duchenne, M., Y. Wang, S. Ben Tahar, and R.N. Beachy. 1998. In vitro stem elongation of sweet pepper in media containing 24-epibrassinolide. Plant Cell Tiss. Org. Cult. 53:79-84.

Golegaonkar, P.G. and A.S. Kantharajah. 2006. High-frequency adventitious shoot bud induction and shoot elongation of Chili pepper (Capsicum annuum L.). In Vitro Cell. Dev. Biol. Plant 42:341-344.

Huetteman, C.A. and J.E. Preece. 1993. Thidazuron: A potent cytokinin for woody plant tissue culture. Plant Cell Tissue Organ Cult. $33: 105-119$
Chen, J., D. Hall, and V. De Luca. 2005. Effects
Husain, S., A. Jain, and S.L. Kothari. 1999. Phenylacetic acid improves bud elongation and in vitro plant regeneration efficiency in Capsicum annuum L. Plant Cell Rep. 19:64-68.

Hyde, C.L. and G.C. Phillips. 1996. Silver nitrate promotes shoot development and plant regeneration of chili pepper (Capsicum annuum L.) via organogenesis. In Vitro Cell. Dev. Biol. Plant 32:72-80.

Kintzios, S., J. Drossopoulos, E. Shortsianitis, and D. Peppes. 2000. Induction of somatic embryogenesis from young, fully expanded leaves of chili pepper (Capsicum annuum L.): Effect of leaf position, illumination and explant pretreatment with high cytokinin concentrations. Sci. Hort. 85:137-144.

Koleva-Gudeva, L.R., M. Spasenoski, and F. Trajkova. 2007. Somatic embryogenesis in pepper anther culture: The effect of incubation treatments and different media. Sci. Hort. 111:114-119.

Kumar, P.P., P. Lakshmanan, and T.A. Thorpe. 1998. Regulation of morphogenesis in plant tissue culture by ethylene. In Vitro Cell. Dev. Biol. Plant 34:94-103.

López-Puc, G., A. Canto-Flick, F. Barredo-Pool, Y. Zapata-Castillo, M. Montalvo-Peniche, F. Barahona-Pérez, and N. Santana-Buzzy. 2006. Direct somatic embryogenesis: A highly efficient protocol for in vitro regeneration of Habanero pepper (Capsicum chinense Jacq.). HortScience 41:1-7.

Lorenzo, J.C., B.L. Gonzalez, M. Escalona, C. Teisson, P. Espinosa, and C. Borroto. 1998. Sugarcane shoot formation in an improved temporary immersion system. Plant Cell Tiss. Org. Cult. 54:197-200.

Martre, P., D. Lacan, D. Just, and C. Teisson. 2001. Physiological effects of temporary immersion on Hevea brasiliensis callus. Plant Cell Tiss. Org. 67:25-35.

Mathew, D. 2002. In vitro shoot and root morphogenesis from cotyledon and hypocotyl explants of hot pepper cultivars Byadagi Dabbi and Arka Lohit. Capsicum and Eggplant Nwsl. 21:69-72.

Mezghani, N., A. Jemmali, N. Elloumi, R. Gargouri-Bouzid, and S. Kintzios. 2007. Morpho-histological study on shoot bud regeneration in cotyledon cultures of pepper (Capsicum annuит). Biologia (Bratisl.) 62:704-710.

Murashige, T. and F. Skoog. 1962. A revised medium for rapid growth and bioassay with tobacco tissue cultures. Physiol. Plant. 15:473497.

Nagaraju, V., G. Bhowmik, and V. Parthasarathy. 2002. Effect of paclobutrazol and sucrose on in vitro cormel formation in gladiolus. Acta Bot. Croat. 61:27-33.

Ochoa-Alejo, N. and L. Ireta-Moreno. 1990. Cultivar differences in shoot-forming capacity of hypocotyl tissues of Chili pepper (Capsicum annuит L.) cultured in vitro. Sci. Hort. 42:2128.

Opatrná, J., P. Novák, and Z. Opatrný. 1997. Paclobutrazol stimulates bud regeneration in Solanum tuberosum L. primary explant cultures. Biol. Plant. 39:151-158.

Pozueta-Romero, J., G. Houlné, L. Cañas, R. Schantz, and J. Chamarro. 2001. Enhanced regeneration of tomato and pepper seedling explants for Agrobacterium-mediated transformation. Plant Cell Tiss. Org. Cult. 67:173-180.

Ramirez-Malagón N. Ochoa-Alejo 1996. An improved and reliable chili pepper (Capsicum annuит L.) plant regeneration method. Plant Cell Rep. 16:226-231.

Reid, M.S. 1995. Ethylene in plant growth, development and senescence, p. 486-508. In: Davis, P.J. 
(ed.). Plant hormones. Kluwer Academia Publishers, Dordrecht, The Netherlands.

Robert, M.L., J.L. Herrera-Herrera, G. HerreraHerrera, M.A. Herrera-Alamillo, and P.A. Fuentes-Carrillo. 2006. New temporary immersion bioreactor system for micropropagation, p. 121-129. In: Loyola-Vargas, V.M. and F. Vázquez-Flota (eds.). Plant cell culture protocols. 2nd Ed Vol 11. Humana Press, Totowa, NJ.

Sanatombi, K. and G. Sharma. 2008. In vitro propagation of Capsicum chinense Jacq. Biol. Plant. 52:517-520.

Santana-Buzzy, N., A. Canto-Flick, F. BarahonaPérez, M.C. Montalvo-Peniche, P.Y. ZapataCastillo, A. Solís-Ruiz, A. Zaldívar-Collí, O. Gutiérrez-Alonso, and M.L. Miranda-Ham. 2005. Regeneration of Habanero pepper (Capsicum chinense Jacq.) via organogenesis. HortScience 40:829-831.

Santana-Buzzy, N., A. Canto-Flick, L.G. IglesiasAndreu, M.C. Montalvo-Peniche, G. LópezPuc, and F. Barahona-Pérez. 2006. Improvement of in vitro culturing of Habanero pepper by inhibition of ethylene effects. HortScience 41:405-409.

Steinitz, B., D. Wolf, T. Matzevich-Josef, and A. Zelcer. 1999. Regeneration in vitro and genetic transformation of pepper (Capsicum spp.): The current state of art. Capsicum and Eggplant Nwsl. 18:8-15.

Steinitz, B., M. Küsek, Y. Tabib, I. Paran, and A. Zelcer. 2003. Pepper (Capsicum annuиm L.) regenerants obtained by direct somatic embryogenesis fail to develop a shoot. In Vitro Cell. Dev. Biol. Plant 39:296-303.

Taylor, P.W.J., H.L. Ko, and T.A. Fraser. 1994 Effect of silver nitrate on sugarcane cell suspension growth, protoplast isolation, ethylene production and shoot regeneration from cell suspension cultures. J. Expt. Bot. 45:11631168.

Thakur, R., A. Sood, K.P. Nagar, S. Pandey, R.C. Sobti, and P.S. Ahuja. 2006. Regulation of growth of Lilium plantlets in liquid medium by application of paclobutrazol or ancymidol, for its amenability in a bioreactor system: Growth parameters. Plant Cell Rep. 25:382391.

Valera-Montero, L. and N. Ochoa-Alejo. 1992. A novel approach for chili pepper (Capsicum annuиm L.) plant regeneration: Shoot induction in rooted hypocotyls. Plant Sci. 84:215-219.

Venkataiah, P., T. Christopher, and K. Subhash. 2001. Plant regeneration and Agrobacteriummediated genetic transformation in four Capsicum species. Capsicum and Eggplant Nwsl. 20:68-71.
Venkataiah, P., T. Christopher, and K. Subhash. 2003. Thidiazuron induced high frequency adventitious shoot formation and plant regeneration in Capsicum annuum L. J. Plant Biotechnol. 5:245-250.

Venkataiah, P., T. Christopher, and K. Subhash. 2006. In vitro shoot multiplication and plant regeneration in four Capsicum species using thidiazuron. Sci. Hort. 107:117-122.

Yusnita, S., R.L. Geneve, and S.T. Kester. 1990. Micropropagation of white flowering eastern redbud (Cercis canadensis var. alba L.). J. Environ. Hort. 8:177-179.

Zapata-Castillo, Y.P., A. Canto-Flick, G. LópezPuc, A. Solís-Ruiz, F. Barahona-Pérez, and N. Santana-Buzzy. 2007. Somatic embryogenesis in Habanero pepper (C. chinense Jacq.) from cell suspensions. HortScience 42:1-5.

Ziv, M. and T. Ariel. 1991. Bud proliferation and plant regeneration in liquid-cultured philodendron treated with ancymidol and paclobutrazol. J. Plant Growth Regul. 10:53-57.

Ziv, M., S. Kahany, and H. Lilien-Kipnis. 1994. Scaled-up proliferation and regeneration of Nerine in liquid cultures. Part I. The induction and maintenance of proliferating meristematic clusters by paclobutrazol in bioreactors. Plant Cell Tissue Organ Cult. 39: 111-117. 